Bangladesh J. Plant Taxon. 26(2): 197-203, 2019 (December)

(C) 2019 Bangladesh Association of Plant Taxonomists

\title{
THREE NEW SPECIES RECORDS OF THE GENUS PINALIA LINDL. (ORCHIDACEAE) FOR BANGLADESH
}

\author{
Mohammed Kamrul Huda, Mohammed Mozammel Hoque \\ and Md. Owahidul Alam \\ Department of Botany, University of Chittagong, Chattogram 4331, Bangladesh
}

Keywords: Pinalia obesa; Pinalia spicata; Pinalia acervata; Orchid; New records; Bangladesh.

\begin{abstract}
Pinalia obesa (Lindl.) Kuntze, Pinalia spicata (D. Don) S. C. Chen \& J. J. Wood and Pinalia acervata (Lindl.) Kuntze of the family Orchidaceae have been reported here as new angiospermic record for Bangladesh flora. Detailed examination with description, flowering time, ecology and geological distribution of the species has been provided here with illustration and photographs.
\end{abstract}

\section{Introduction}

Orchidaceae represents the highly evolved family comprising 25,000-35,000 species and 600800 genera (Dressler, 1993). The largest number of orchids is found in tropical America comprising 360 genera and 8,266 species while tropical Asia in second with 250 genera and 6800 species (Dressler, 1990). In Indian flora this is the second largest family represented with 130 genera and over 880 species distributed mainly in Eastern Himalayas, Western Ghats and Khasia Hills (Sharma, 2000). Bangladesh is also rich in orchids with 179 taxa under 70 genera (Huda, 2008). Now the family is recognized to be represented in the flora by 74 genera and 188 species, of these, 117 species under 41 genera are epiphytic in nature and 71 species under 33 genera are terrestrial (Rahman et al., 2017). Most of the orchid species are distributed mainly in the hilly areas of greater Sylhet, Chittagong, Chittagong Hill Tract and Mymensingh district (Alam et al., 1993).

The genus Pinalia Lindl. is one of the larger polymorphic genera of the family Orchidaceae. It has about 404 species all over the world (Royal Botanical Gardens, Kew 2003) which are divided into 13 to 17 sections according to the nature of pseudobulbs and leaf characters (Seidenfaden, 1982; Pearce and Cribb, 2002). It is now widespread in tropical Asia, extending east to New Guinea, Australia and the Pacific Islands. From Bangladesh, no species of this genus have been recorded so far (Huda, 2008). Pinalia is characterized by its small flowers in dense or lax, cylindrical or globular; lip with side-lobes and keels; column foot hollowed at its upper side, upward curved distally and firmly connected to the short claw at the base of lip, without a geniculate band or distinct joint (Agrawala and Lal, 2012).

In the present study, three species of the Pinalia Lindl. have been identified as new record from Bangladesh. The vegetative plants of these three species were collected from Bandarban district of Bangladesh. The collected plants were grown at the orchidarium. After flowering of the both species, the flower of each species were dissected and critically examined under microscope and then identified with the consultation of the relevant literature (Lindley 1830-40, Hooker 1890, Prain 1903, Heinig 1925, Sinclair 1955, Seidenfaden, 1982, Pearce and Cribb 2002). The voucher specimens of each species have been deposited at the Herbarium of Chittagong University (HCU).

*Author for correspondence, Email: mkhuda70@hotmail.com 


\section{Taxonomic description}

1. Pinalia obesa (Lindl.) Kuntze, Revis. Gen. Pl. 2: 679 (1891).

Eria obesa Lindl. in Wall. Cat. 1976; Gen. and Sp. Orchid. 68; in Bot. Reg. 1844, Bot. Reg. Sub. t. 29, 53; Hooker f.1890, Fl. Brit. Ind. 5: 793; Grant, 1895; Orchids of Burma 143: Kranzlin in Engler A. (eds.) Das Pflanzenreicn Hfl. 1911, 50: 82; Seidenfaden, 1982, Opera Botanica 62: 105. Eria lindleyana Griff. 1851, Not. 3:300; Eria prini Briquet 1900, Ann. Cons. et. Jard. Bot. Geneva. 4:210. Trias obesa (Lindl.) Mason, Burmah, ed. 3: 809 (1860). Hymeneria obesa (Lindl.) M. A. Clem. \& D. L. Jones, Orchadian 13: 501 (2002).

Epiphytic herbs, $15-17 \mathrm{~cm}$ high. Pseudobulbs very stoutly, clavate ovate, 4-7 cm long, silvery green and with scarious sheaths, leaf sheath $1-1.5 \mathrm{~cm}$ long, brown, scarious. Leaves shed before the flowering. Develop in autumn, about 5-6 leaves and $12 \times 1 \mathrm{~cm}$ appear before the pseudobulbs started swelling, lanceolate or ovate-lanceolate or glabrous; rachis $1 \mathrm{~cm}$ long. Inflorescence raceme, lateral sub-corymbose, 2-4 in numbers, puberulous. Floral bracts up to $3 \mathrm{~mm}$ long, ovate, thin, entire, reflexed at the junction of the stalks, acute; pedicel plus ovary 1.4-2 mm long, pubescent. Flowers white, $2 \mathrm{~cm}$ across in diameter, glabrous. Sepals unequal, 1.0-12 cm long; dorsal sepal lenceolate, acuminate, entire, $1-1.2 \mathrm{~cm} \times 2 \mathrm{~mm}$, glabrous with 5 veins. Lateral sepals lanceolate, slightly oblique, falcate acuminate $12 \times 1.5-3 \mathrm{~mm}$, entire, white, glabrous, thin, 5veins: mentum $1 \mathrm{~mm}$, round, curved, subcoric. Petals oblong-lanceolate, obtuse, 10-12 $\times 2 \mathrm{~mm}$, thin, glabrous and 3 veins; labellum nearly as long as sepals and petals, linear-oblong, obscurely uniformed, thin 3 thickened keels with lateral lobe veins, edges of lobed some with lateral lobe veins, edges of lobed somewhat thin. Column 3-4 mm long, $3 \mathrm{~mm}$ in diameter, white, glabrous, curved, foot 4-5 mm long, concave; operculum up to $1 \mathrm{~mm}$ long, sub-orbicular, thick, pappus at the upper surface, two lobed within 8 chambered; clinandrium collar like, erect posterior acute, 1 dentate; rostellum minute and ligulate. Pollinia 8, obovoid, laterally compressed in appendiculate, attached to glandular caudicle; viscidium simple. Stigmatic cavity $1.5-3 \mathrm{~mm}$ long, curved, low stigma obscured furrow or groove, two long lobes inside the cavity (Plate 1; Fig. 1).

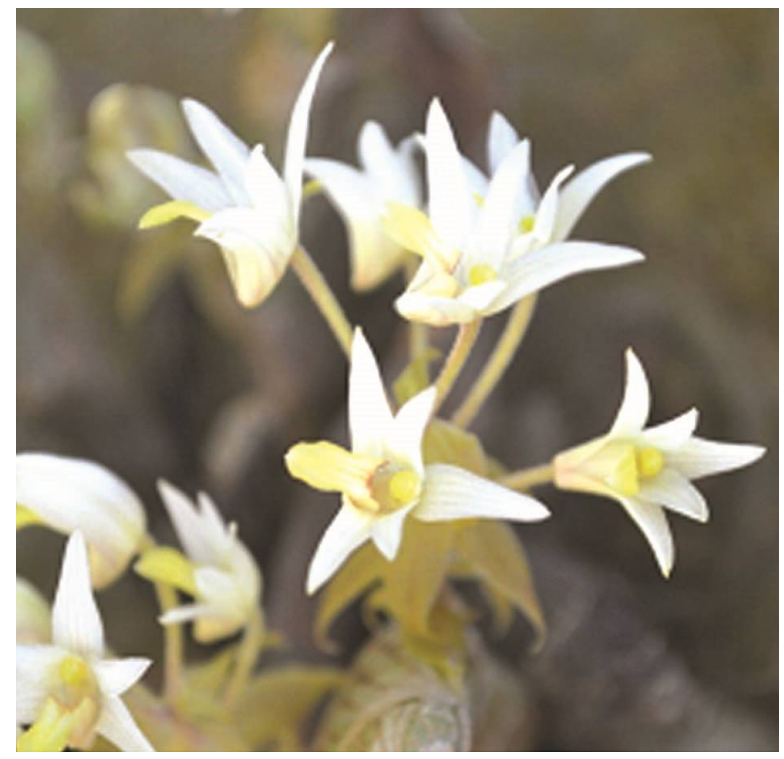

Plate 1. Pinalia obesa (Lindl.) Kuntze. 


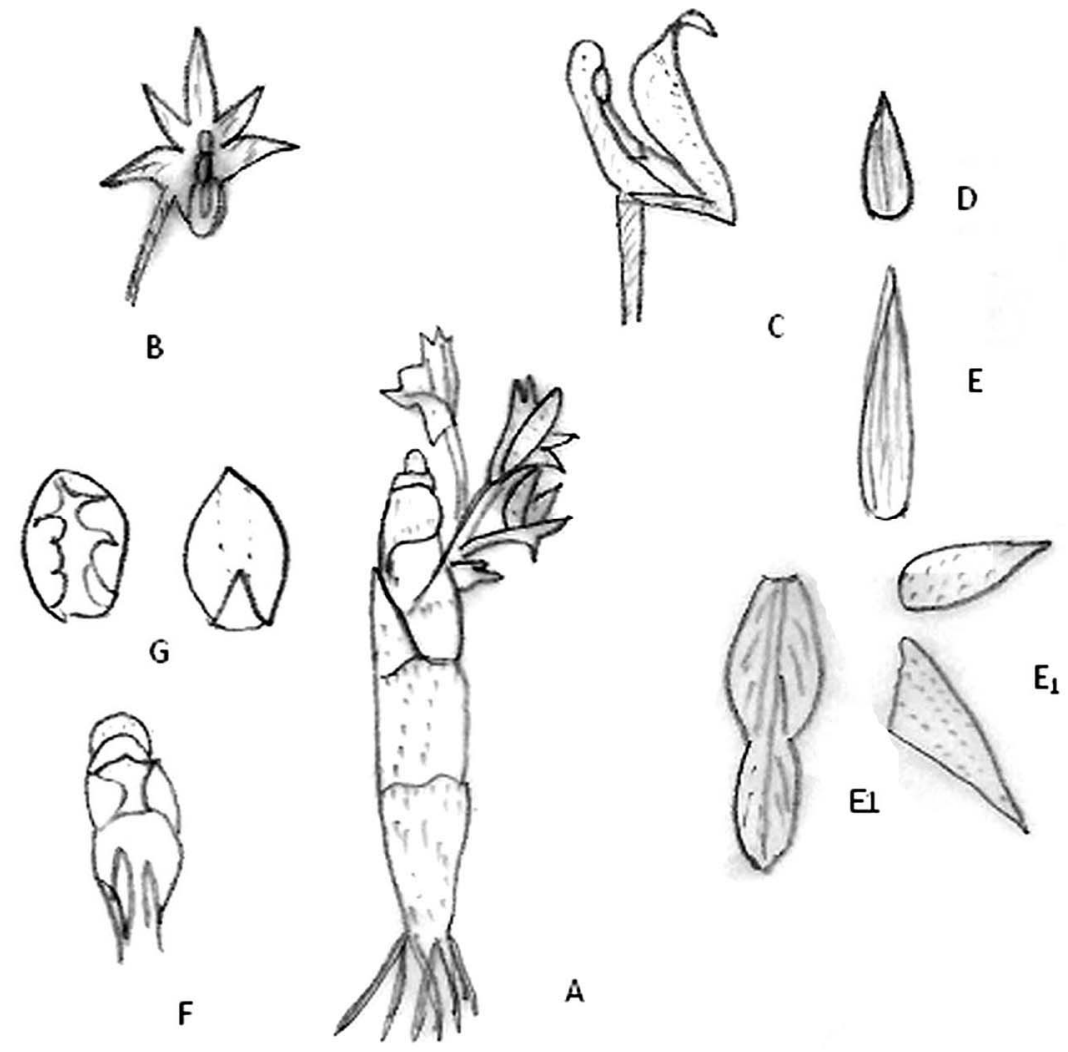

Fig. 1. Pinalia obesa (Lindl.) Kuntze. A) habit; B) flower; C) lateral view of column with labellum; D) bract; E) spreading of sepal, petal; E1) labellum; F) column; G) operculum.

Flowering period: January to February

Ecology: This epiphytic orchid was collected in vegetative stage from Litsia polyantha Juss. tree at high altitude. This orchid was aggregated in clump and it was also found to associate with ferns and Hoya sp.

Distribution: Bangladesh, Nepal, North East India, Mayarmar and Thailand. In Bangladesh the species found to occur in Nilgiri, Bandarban.

Specimen examined: Bandarban; Nilgiri, Jibonnagar Pahar,09.04.2018, M.K. Huda, M.M. Hoque, and M.O. Alam 201(HCU).

2. Pinalia spicata (D. Don) S. C. Chen \& J. J. Wood, Fl. China 25: 354 (2009).

Eria spicata (D. Don) Hand.-Mazz., Symb. Sin. 7: 1353(1936); Octomeria spicata D. Don. Prodr. Fl. Nepal.: 31, 1825; Pinalia alba Buchanan-Hamilton ex D. Don, Prodr. Fl. Nepal.: 31, 1825; Eria convallarioides Lindl. in Wall. Cat: 1975, 1829; Octomeria convallarioides Wall. In Lindl.,lc. Cit., 1830; Eria convallarioides var. major Lindl.in Bot. Reg. 33: t. 63 (1847); E. salwinensis Hand.-Mazz., Symb. Sin.7: 1352, 1936. 
Plants epiphytic, 23-30 cm tall. Pseudobulbs tufted, compressed, sheathed when young, 3.5$12 \times 0.8-1.8 \mathrm{~cm}$; sheaths membranous, overlapping, elliptic-lanceolate, acute, $5-7 \times 1.5-2 \mathrm{~cm}$. Leaves 4-6, elliptic-lanceolate, oblong-lanceolate to oblanceolate, acute, sub coriaceous, manyveined, petiolate, $8-28 \times 0.6-4.5 \mathrm{~cm}$; petiole grooved, $1.5-5 \mathrm{~cm}$ long. Inflorescence axillary, decurved, broadly cylindric, densely many-flowered, glabrous, 5-7 $\times 1-1.5 \mathrm{~mm}$. Flowers subglobose, glabrous, 3-6 mm across, white or pale straw-coloured, lip tinged with yellow, column tinged with red; pedicel and ovary puberulent, $2-4 \mathrm{~mm}$ long. Sepals sub similar, broadly ovate, obtuse, 3-5 × 1.5-3.5 mm; lateral sepals concave. Petals oblanceolate-oblong, spreading, $3-$ $7 \times 1.5-3 \mathrm{~mm}$. Lip obscurely 3-lobed, wedge-shaped, concave, apex subacute, $3 \mathrm{~mm}$ long; disc lacking lamellac. Column slender, 2-4.5 mm long; foot incurved. Fruit cylindric-ovoid, 5-9 × 5-6 mm (Plate 2; Fig. 2).

Flowering period: March

Habit: The species was found to grow on the trunk of the host tree Garuga pinnata (Gaertn.) Roxb.

Distribution: Bangladesh, North East India, Nepal, Myanmar, China and Thailand. In Bangladesh, the species was found in Keokaradung Mountain, Ruma, Bandarban.

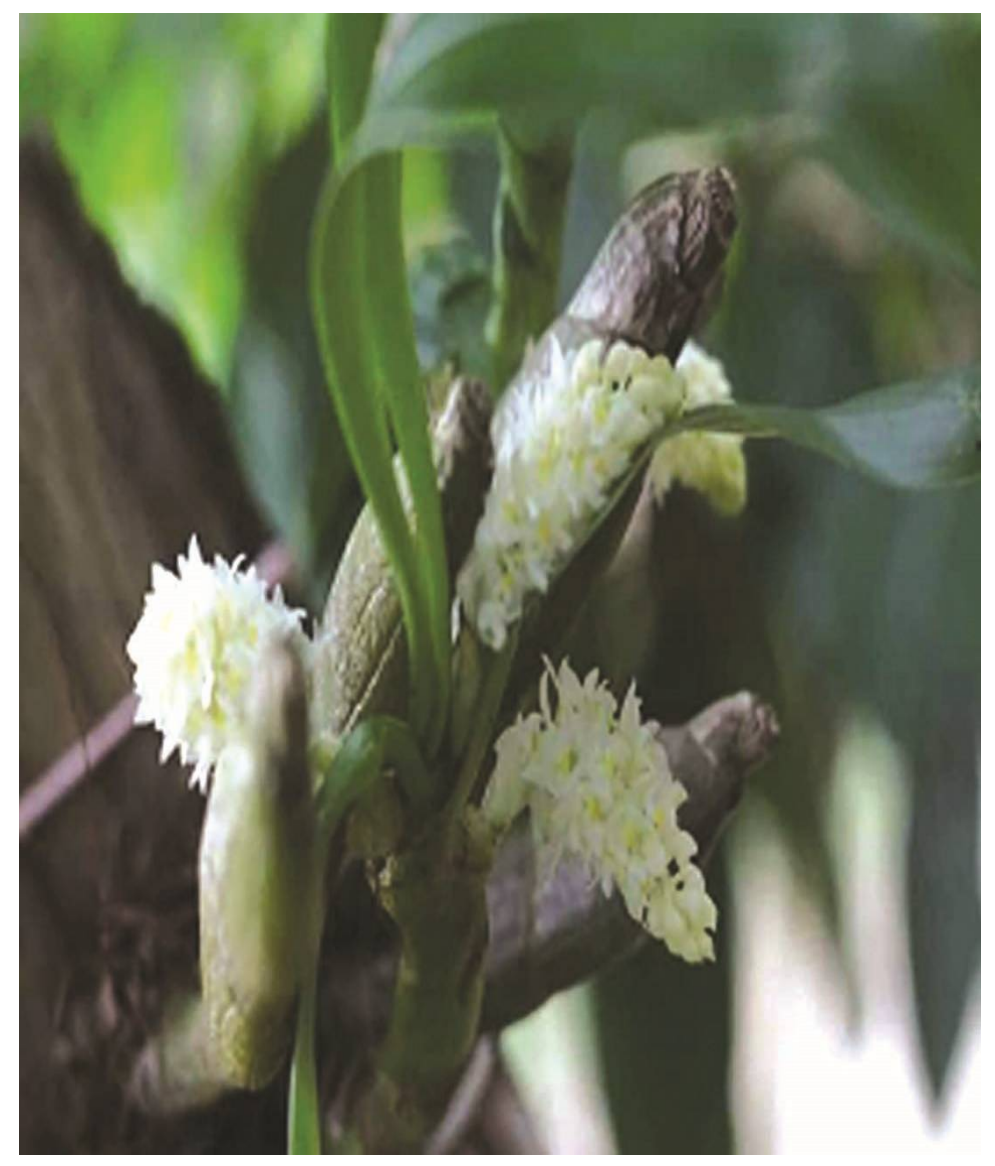

Plate 2. Pinalia spicata (D. Don) S. C. Chen \& J. J. Wood. 


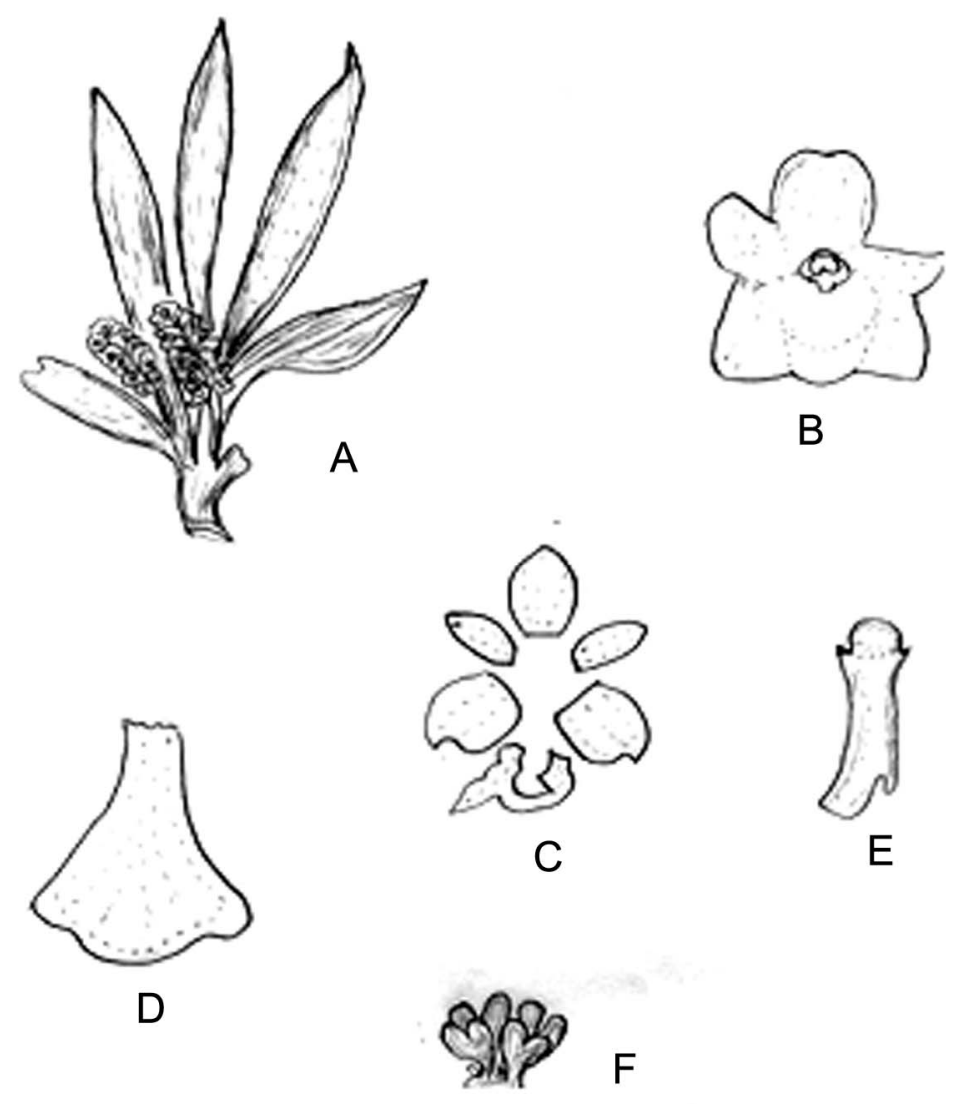

Fig. 2. Pinalia spicata ( D. Don) S. C. Chen \& J. J. Wood. A) habit; B) flower; C) pedicel, ovary, sepals, petals, lip, column and foot; D) lip; E) column; F) pollinia.

Specimen examined: Bandarban; Keokaradung Mountain, Ruma, 10.04.2018, M.K. Huda, M.M. Hoque, and M.O. Alam 202 (HCU).

3. Pinalia acervata (Lindley) Kuntze, Revis. Gen. Pl. 2: 679. 1891.

Eria acervata Lindley, J. Hort. Soc. London 6: 57. 1851

Pseudobulbs usually 2 or 3 , or sometimes 8 closely and regularly arranged into a row, fusiform, sometimes bottle-shaped, sometimes compressed, $2-4 \times 0.6-1.5 \mathrm{~cm}$, apex 2-4-leaved. Leaves sessile, oblong-lanceolate, $4-10 \times 0.8-2 \mathrm{~cm}$, base attenuate, apex obtuse and slightly unequally 2-lobed. Inflorescences 1-3, subterminal, 3-6 cm, 4-7-flowered; rachis glabrous; floral bracts ovate or ovate-lanceolate, $0.5-1 \mathrm{~cm}$, margin sparsely denticulate, apex long acuminate. Flowers white, sepals tinged green at apex, lip yellow; pedicel and ovary $1 \mathrm{~cm}$. Dorsal sepal narrowly ovate, $6 \times 2 \mathrm{~mm}$, 5-veined, acuminate; lateral sepals falcate-lanceolate, $7 \times 5$-6 mm, acuminate. Petals lanceolate, $6 \times 2 \mathrm{~mm}$, obtuse; lip broadly cuneate in outline, $7 \times 6 \mathrm{~mm}$, base attached to column foot at a right angle, 3-lobed; lateral lobes falcate-oblong, $2 \mathrm{~mm}$ wide; midlobe orbicular, $3 \times 3 \mathrm{~mm}$; disk with 3 keeled lamellae from base to middle of mid-lobe. Column 3 $\mathrm{mm}$; foot $4 \mathrm{~mm}$. Capsule narrowly cylindric, $2.7 \times 0.4 \mathrm{~cm}$ (Plate 3; Fig. 3). 
Flowering period: August

Ecology: The species was found to grow on the trunk of the host tree Garuga pinnata (Gaertn.) Roxb.

Distribution: Bangladesh, Bhutan, Bhutan, Cambodia, NE India, Laos, Myanmar, Nepal, Thailand. In Bangladesh, the species was found in Keokaradung Mountain, Ruma, Bandarban.

Specimen examined: Bandarban; Keokaradung Mountain, Ruma, 10.04.2018, M.K. Huda, M.M. Hoque, and M.O. Alam 211 (HCU).

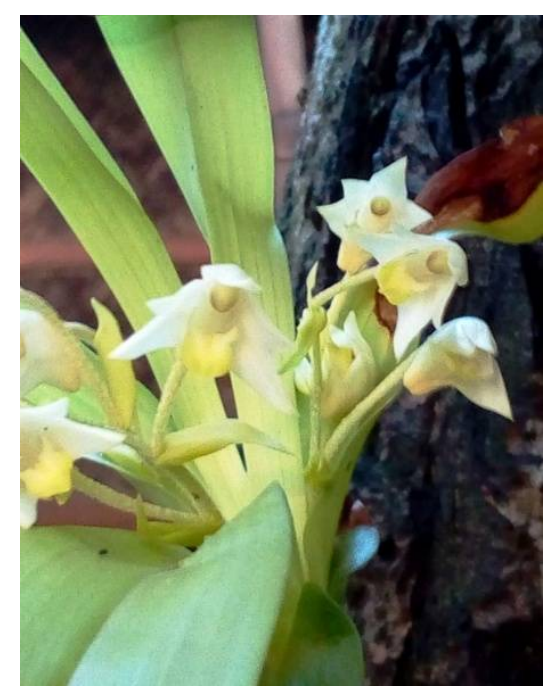

Plate 3. Pinalia acervata (Lindl.) Kuntze.
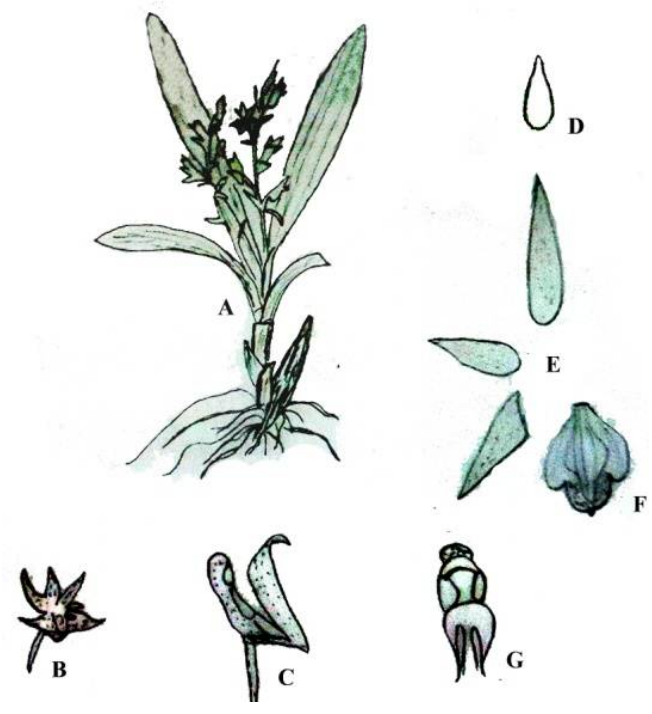

Fig. 3. Pinalia acervata (Lindl.) Kuntze. A) habit; B) flower; C) lateral view of column with labellum; D) bract; E) spreading of sepal, petal; F) labellum; G) column. 


\section{Acknowledgement}

The authors gratefully acknowledge the Ministry (MoE) of Education, Government of the People's Republic of Bangladesh for the financial support under Grants for Advanced Research in Education (GARE) project to conduct the research and Department of Botany, University of Chittagong for logistic support. The authors are also grateful to Mr. Amir Hossen Nayan for his cooperation during collection of the specimens.

\section{References}

Agrawala, D. K. and Lal, K. 2012. Extended distribution of Eria spicata (Orchidaceae), a curious sympodial orchid from the India subcontinent. www.richardiana.com. pp. 80-91.

Alam, Sk. S., Kondo, K. and Tanaka, R. 1993. A chromosome study of eight Orchid species in Bangladesh. La Kromosome. pp. 71-72.

Dressler, R. L. 1990. The Orchids natural history and classification, Harvard University Press, London $\left(2^{\text {nd }}\right.$ edn).

Dressler, R. L. 1993. Phylogeny and classification of the orchid family press Syndicate of the University of Cambridge, Australia.

Heinig, R. L. 1925. List of plant of Chittagong collectorate and Hill Tracts. Derjeeling, pp. 68-70.

Hooker, J. D. 1890. The flora of British India.Vol 5. Kent (England): L. Reeve and Co. Ltd. pp. 1-910 .

Huda, M. K. 2008. Orchidaceae. In: Ahmed, ZU, Hassan, MA, Begum, ZNT, Khondker, M, Kabir, SMH, Ahmad, M, Ahmed, ATA, Rahman, AKA and Haque, EU (Eds.). Encyclopedia of Flora and Fauna of Bangladesh. Asiatic Society of Bangladesh, Dhaka.12: 1-149.

Lindley, J. 1830-1840. Eria. In: The genera and species of orchidaceous plants. London: Ridgways. pp. 6871.

Pearce, N. R. and Cribb, P. J. 2002. The flora of Bhutan. The orchids of Bhutan. Edinburgh (UK): The Royal Botanic Garden and Bhutan. The Royal Government of Bhutan. 2 (3): 643 p.

Prain, D. 1903. Bengal Plants. India reprint (1966). Botanical survey of India, Calcuta, 2: 750-772.

Rahman, M. A., Huda, M. K. and Rashid, M. E. 2017. Orchid Species Diversity in Bangladesh and their Revised Nomenclatural Updates, Biodiversity Bulletin Bangladesh. 10: 1-70.

Royal Botanic Gardens. Kew.2003. Monocot checklist. Available: http://www.rbgkew.org.uk/data/monocots via the INTERNER.

Seidenfaden, G. 1982. Orchid genera in Thailand X. Trichotosia Bl. and Eria Lindl. Opera Botanica. 62: 157.

Sharma, O. P. 2000. Orchidaceae, In: Plant Taxonomy. Tata Mc Grew-Hill publishing Co, Rajkamal Electric Press, New Delhi, India. pp. 18-42, 297-301.

Sinclair, J. 1956. The flora of Cox's Bazar, East Pakistan. Bull. Bot. Soc. Beng., Calcutta, India. 9(2): 107108. 